\title{
Relational Embeddedness in Mentoring Relationships between Prospective K-12 Education Leaders and Their Mentor Principals
}

\author{
Maridee Beeston Ph.D* \\ Department of Educational Leadership \& Foundations Brigham Young University
}

*Corresponding Author: Maridee Beeston Ph.D, Department of Educational Leadership \& Foundations Brigham Young University

\begin{abstract}
Education leaders face challenges in demanding environments often lacking critical resources necessary to make a difference in schools. The potential to acquire these resources may be found in mentoring relationships formed during internships during educational leadership preparation programs.
\end{abstract}

There is a lack of understanding regarding variations in the nature of mentoring relationships-specifically in terms of relational embeddedness - the type and degree to which partners form ties. Relational embeddedness may impact mentoring quality and the potential to acquire the resources needed to succeed in school environments.

Frameworks in mentoring and social network theory were used in this quantitative study to examine the nature of relational embeddedness and its association with a variety of internal and external factors which may influence relational embeddedness development and outcomes in mentoring relationships.

Key words: mentoring, social network theory, relational embeddedness, educational leadership preparation.

\section{BACKGROUND}

Principals are central to the task of leading schools that promote powerful teaching and learning (Davis, Darling-Hammond, LaPointe, \& Meyerson, 2005). In fact, among school-based factors, leadership is second only to classroom instruction as a strategy to increase student learning (Leithwood, Anderson \& Wahlstrom, 2004).Regarding the significant challenges faced by today's education leaders, Fullan (2009) stated: "Principals are expected to be miracle worker[s] who can do more with less, pacify rival groups, endure chronic second-guessing, tolerate low levels of support, process large volumes of paper and work double shifts" (p. 59). In addition to these demanding responsibilities, principals are expected to be change agents accountable for instructional leadership to ensure that all children achieve (DiPaola \& Tschannen-Moran, 2003). As a result of these conditions, many principals are overloaded in a way that makes it difficult to fulfill the promise of widespread and sustained reform (Fullan, 2009).

How school leaders are prepared has implications for what happens to enhance the teaching and learning of students (Crow, 2012; Levine, 2006).Elmore (2008) cautioned, "School leaders are being asked to assume responsibilities they are largely unequipped to assume, and the risks and consequences of failure are high for everyone, but especially high for children" (p. 43). Thus, prospective school leaders must be equipped with the tools necessary to overcome challenges and make a difference in schools (Levine, 2006).

The research on effective educational leadership preparation program design indicates one key to the development of effective school leadership may be found in high-quality mentoring relationships as part of authentic internship experiences (Hite, Williams, \& Baugh, 2005). A key indicator of high quality in mentoring may be relational embeddedness - the type and degree to which partners form ties - which stands to affect possible resource acquisition and other outcomes (Fletcher \& Ragins, 2007; Hite \& Matthews, 2005).

A lack of understanding exists regarding the nature of relational embeddedness and therefore, the resources and outcomes that may result from its development. Outcomes such as the level of trust, the amount of information and other resources that are exchanged, and the degree to which future school 
leaders acquire the tools necessary to take on the complex roles required to successfully lead schools may all be affected by relational embeddedness (Hite \& Matthews, 2005).

This study represents an initial examination of relational embeddedness in mentoring relationships in educational leadership preparation program internships and lays the groundwork for future research. When program administrators understand the nature of relational embeddedness, they may be better informed to design effective internship experiences that promote relational embeddedness development to prepare future leaders with the necessary resources to positively impact their leadership and raise student achievement.

\section{Mentoring Relationships}

Traditional forms of mentoring have been characterized by descriptions of a wise mentor who shapes and guides the life of a younger, less-experienced protégé. As early as 1983, Merriam offered a definition of mentoring as a "powerful emotional interaction between an older and younger person, a relationship in which the older member is trusted, loving and experienced in the guidance of the younger" (p. 162). Current research suggests, however, that traditional definitions of mentoring may not meet the needs of individuals facing diverse and dynamic organizational contexts and careers (Ehrich, Hansford, \& Tennent, 2004). Fletcher and Ragins (2007) expanded a definition of mentoring to reflect a more relational approach as an "interdependent and generative developmental relationship that promotes mutual growth, learning and development" (p. 374).Thus, partners in relational mentoring ties are responsible for their own learning and assist the learning and development of the other thereby increasing potential benefits (Fletcher \& Ragins, 2007). These benefits may include increased compensation and promotion (Allen, Lentz, \& Eby, 2006; Ehrich, et al., 2004), as well as psychosocial rewards such as friendship and support (Kram, 1983).

Since learning and development can be increased in relationship with others, mentoring ties formed during educational leadership preparation program internships can provide valuable opportunities for prospective education leaders to test and improve their skills as they prepare to be leaders in today's schools (Crow, 2012; Daresh, 2004; Davis, et al., 2005). Daresh (2004) suggested five major benefits to prospective education leaders from mentoring as follows: (a) increased confidence about professional competence, (b) applied educational theory from university coursework applied to actual practice, (c) improved communication skills, (d) added tricks of the trade from professionals in the field, and (e) expanded socialization in new settings as prospective school leaders. Clearly, mentoring relationships can be a key social structure through which critical resources of knowledge, skills and dispositions necessary for effective leadership preparation may flow.

The quality of mentoring relationships, like all social relationships, may be affected by a variety of internal and external factors. The literature suggests internal factorssuch as demographic and behavioral characteristics shape the quality of mentoring (Clutterbuck2005; Fletcher \& Ragins, 2007). For example, Orland-Barak and Hasin (2010) stated that mentors with organizational skills, knowledge and expertise were linked to the quality of mentoring relationships. Clutterbuck (2005) also indicated mentor competencies such as listening, giving feedback, building trust and engaging in reciprocal behavior enhanced the quality of the mentoring. Mentees also contribute in ways that affect relationship quality and potential outcomes. Proactivity, initiation, and help-seeking behavior were among characteristics connected with high-quality mentoring outcomes (Wanberg, KammeyerMueller, \& Marchese, 2006). External factors embedded in the social context may also influence mentoring quality and outcomes.

\section{SOCIAL NETWORK THEORY}

The mentoring relationship between a prospective education leader and their mentor principal represents a dyadic network tie that can be usefully explored using the theoretical framework of social network theory. According to social network theory, a dyadic tie consists of two individuals and the tie that connects them. Sets of connected dyadic ties form the structure that surround the mentoring relationship (Granovetter, 1973; Hite, 2003; Hite \& Matthews, 2005). Hite (2008) emphasized the potential of these dyadic ties, stating, "dyadic ties represent potential bridges, conduits, or pipes 
through which different types of content may flow or be exchanged" (p. 139). Thus, the dyadic tie represents the pathway through which social content and necessary human resources such as knowledge and skills can be acquired or exchanged.

Just as social relationships may differ, dyadic ties may be expected to vary. Social network theory can explain variations in social relationships and dyadic ties in terms of relational embeddedness. Relational embeddedness describes the nature of the dyadic tie that connects mentoring partners as part of the social network. The roots of relational embeddedness stem from Granovetter's (1973) early work describing ties as either strong or weak. Granovetter reinforced the importance of relational embeddednessas it can shape both the action and the affect within the tie (Granovetter, 1973; Hite, 2003).

The literature in social network theory describes a variety of antecedents tothe nature of relational embeddedness using internal and external constructs similar to those described in the mentoring literature. Internal factors such as demographic and behavioral aspects, as well as external elements in which the tie is embedded characterize these antecedents. Both internal and external factors may impact the development and the variation of relational embeddedness and generate differential outcomes (Granovetter, 1973).

Some internal and external factors in the mentoring relationship may seem fixed while other characteristics - particularly those associated with the development of relational embeddedness - are dynamic and can be changed (Granovetter, 1973; Hite, 2008). Thus, a variety of internal and external factors in a mentoring relationship may affect variations in relational embeddedness.

Variations of relational embeddedness may influence mentoring outcomes. Mentoring outcomes such as the level of trust that is established, joint problem solving, commitment and resource exchange may be among those characteristics affected by relational embeddedness (Granovetter, 1973; Hite, 2003). The research also suggests organizational benefits, such as innovation or entrepreneurial expansion, may be increased through relationally-embedded ties (Granovetter, 1973; Hite, 2005).

To operationalize the construct of relational embeddedness, Hite (2003) argued that dichotomies which describe relational embeddedness as simply strong or weak are insufficient to capture the inherent variation of these dyadic ties. Therefore Hite (2003) proposed a multidimensional classification typology which identifies varying degrees and types of the multidimensional nature of relational embeddedness (see Figure 1).

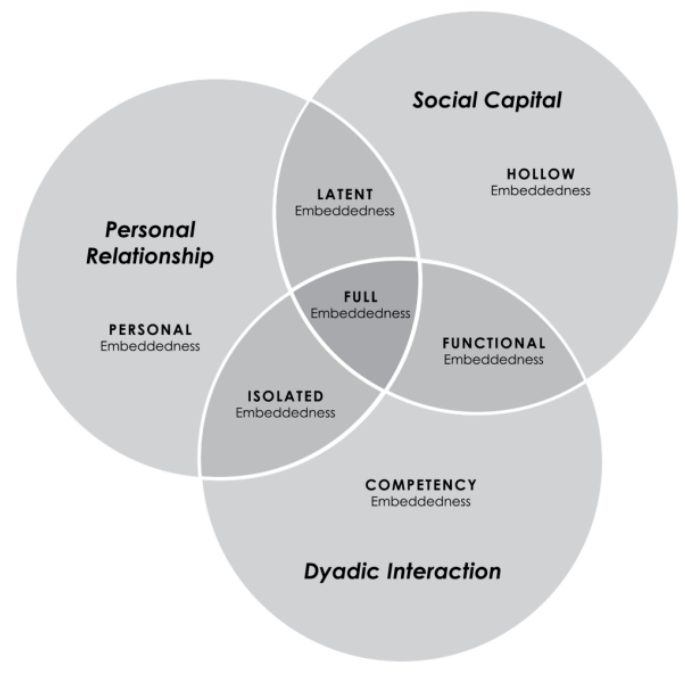

Figure1. Typology of Relational Embeddedness (Adapted from Hite, 2003)

The source of variety, indicated in Hite's typology (2003), is represented by three social components that can be identified and described. Personal relationship - often considered to be the equivalent of the social relationship - is just one of three social components. It is comprised of knowledge of each other's persona, needs, and interests; affect - extent of feelings such as respect, loyalty and care; and sociality outside the mentoring context. The second social component, dyadic interaction, reflects the 
Relational Embeddedness in Mentoring Relationships between Prospective K-12 Education Leaders and Their Mentor Principals

history or processes of the exchange between the partners. The attributes of dyadic interaction include the extent, frequency, amount, duration or intensity of the interactions; the effort expended in behalf of the other; and the ease in responsiveness and quality of the communication. The third social component is social capital with the attributes of obligations, expectations and norms established and reciprocated; the accessibility of available resources; and brokering or enlisting additional networks outside the tie (see Table 1).

Table1. Relational Embeddedness Type, Social Component(s), Attributes and Degree

\begin{tabular}{|c|c|c|c|c|}
\hline $\begin{array}{l}\text { Number } \\
\text { Key }\end{array}$ & Type & $\begin{array}{l}\text { Social } \\
\text { Component(s) }\end{array}$ & Attributes \& Description & Degree \\
\hline 1 & Personal & $\begin{array}{l}\text { Personal } \\
\text { Relationship }\end{array}$ & Knowledge, Affect, Sociality & $\begin{array}{l}\text { Uni-dimensional } \\
\text { Embeddedness }\end{array}$ \\
\hline 2 & Competency & $\begin{array}{l}\text { Dyadic } \\
\text { Interaction }\end{array}$ & Extent, Effort, Ease & $\begin{array}{l}\text { Uni-dimensional } \\
\text { Embeddedness }\end{array}$ \\
\hline 3 & Hollow & Social Capital & $\begin{array}{l}\text { Obligations, Resource Accessibility, } \\
\text { Brokering }\end{array}$ & $\begin{array}{l}\text { Uni-dimensional } \\
\text { Embeddedness }\end{array}$ \\
\hline 4 & Isolated & $\begin{array}{l}\text { Personal } \\
\text { Relationship } \\
\text { Dyadic } \\
\text { Interaction }\end{array}$ & $\begin{array}{l}\text { HighKnowledge, Affect, Sociality; } \\
\text { HighExtent, Effort, Ease } \\
\text { Low Obligations, Resource } \\
\text { Accessibility Brokering }\end{array}$ & $\begin{array}{l}\text { Bi-dimensional } \\
\text { Embeddedness }\end{array}$ \\
\hline 5 & Functional & $\begin{array}{l}\text { Dyadic } \\
\text { Interaction } \\
\text { Social Capital }\end{array}$ & $\begin{array}{l}\text { HighExtent, Effort, Ease; } \\
\text { High Obligations, Resource } \\
\text { Accessibility, Brokering } \\
\text { LowKnowledge, Affect, Sociality }\end{array}$ & $\begin{array}{l}\text { Bi-dimensional } \\
\text { Embeddedness }\end{array}$ \\
\hline 6 & Latent & $\begin{array}{l}\text { Social Capital } \\
\text { Personal } \\
\text { Relationship }\end{array}$ & $\begin{array}{l}\text { High Obligations, Resource } \\
\text { Accessibility, Brokering } \\
\text { HighKnowledge, Affect, Sociality } \\
\text { LowExtent, Effort, Ease }\end{array}$ & $\begin{array}{l}\text { Bi-dimensional } \\
\text { Embeddedness }\end{array}$ \\
\hline 7 & Full & $\begin{array}{l}\text { Personal } \\
\text { Relationship } \\
\text { Dyadic } \\
\text { Interaction } \\
\text { Social Capital }\end{array}$ & $\begin{array}{l}\text { HighKnowledge, Affect, Sociality } \\
\text { HighExtent, Effort, Ease } \\
\text { High Obligations, Resource } \\
\text { Accessibility, Brokering }\end{array}$ & Fully Embedded \\
\hline 8 & $\begin{array}{l}\text { Not- } \\
\text { Embedded }\end{array}$ & None & $\begin{array}{l}\text { No high-degree of any of the Social } \\
\text { Components }\end{array}$ & No Embeddedness \\
\hline
\end{tabular}

Various combinations of these social components, when present at a high level, result in varying degrees and types of relational embeddedness. Higher degrees of the social components offer more advantages over degrees that lack specific social components. For example, uni-dimensional relational embeddedness consisting of the attributes of only one social component "may be neither as stable nor as effective as more developed relationally embedded ties" (Hite, 2003 p. 35). Fully embedded ties, on the other hand, demonstrate high levels of all three social components and present a greater likelihood of benefits and resources. Types of relational embeddedness are classified as follows: (a) personal, (b) competency, (c) hollow, (d) isolated, (e) functional, (f) latent (g) full embeddedness and (h) not-embedded (see Table 1).

To measure relational embeddedness in dyadic ties, Hite, Wakkee, Hite, Sudweeks and Walker (2011) developed the Typology of Relational Embeddedness Network Data Survey (TRENDS). Based on participants' responses, this validated network survey instrument measures the extent of the three social components and classifies dyadic ties according to degree and type of relational embeddedness. Hite's (2003) Typology of Relational Embeddedness, with the TRENDS instrument (Hite et al., 2011),offers a useful perspective from which to examine the mentoring relationships between prospective education leaders and their mentor principals in educational leadership preparation program internships.

\section{RESEARCh PROBLeM}

Prospective education leaders face challenges in demanding environments often lacking resources needed to make a difference in schools. The potential to acquire these resources may be found in mentoring relationships formed during educational leadership preparation program internships. While 
mentoring is a key component of many programs, a lack of understanding exists regarding variations in the nature of these mentoring relationships - specifically in terms of relational embeddedness. It is important to understand these variations because relational embeddedness may affect the quality of the relationship and the potential outcomes needed by school leaders to impact student learning.

To address the need to understand the nature of relational embeddedness this study examines the mentoring relationships between prospective K-12 education leaders and their mentor principals. Using the Typology of Relational Embeddedness (Hite 2003), and the TRENDS survey instrument (Hite et al. 2011), this research demonstrates a way to measure and identify degrees and types of relational embeddedness that may affect the quality of mentoring relationships and the potential outcomes associated with effective education leader preparation.

\section{Research Questions:}

1. What is the nature of relational embeddedness in the mentoring relationships between prospective $\mathrm{K}-12$ education leaders and their mentor principals in educational leadership preparation program internships?

2. How are internal factors of the prospective K-12 education leaders and their mentor principals associated with the relational embeddedness in the mentoring ties?

3. How are external factors in the context in which the mentoring relationship is embedded associated with the relational embeddednessin the mentoring ties?

Browne-Ferrigno and Muth (2004) stated that high-quality mentoring relationships "improve, expand and deepen leadership capacity in schools" (p. 489). While these outcomes are outside the immediate scope of this research, understanding the nature of relational embeddedness and the antecedents which influence its development may lay the foundation for future research of effective school leadership outcomes.

\section{METHODS}

This study utilizes theoretical frameworks in mentoring and social network theory to examine the nature of relational embeddedness in the mentoring relationships between prospective K-12 education leaders and their mentor principals. Associations between relational embeddedness and the internal factors of the partners in a mentoring relationship and external factors in the context in which the mentoring relationship is embedded are also explored.

The specific case under examination is an educational leadership preparation program at a western university. The program has prepared education leaders for nearly three decades and generally accepts up to 30 candidates each year. Candidates complete the program within either a full- or part-time internship structure. Key components of both internship structures are mentoring experiences in actual K-12 school settings. Educational leadership preparation program administrators, in partnership with neighboring school districts, broker or match the mentoring partnerships between prospective education leaders as the mentees and established principals as their mentors. After the successful completion of the program, candidates receive a Masters of Education degree (M.Ed.). In the study period, $91 \%$ of the candidates pursued and received administrative licenses from the state.

\subsection{Sample}

The population for this study includes all licensed schoolteachers in educational leadership preparation programs. The purposive sample consisted of prospective K-12 education leaders enrolled in the university's educational leadership preparation program during the years 2010 to $2014(\mathrm{n}=118)$. A total of $47(40 \%)$ of the sample completed the survey. The gender composition of this sample was $58 \%$ female and $42 \%$ male. All participants ranged in age from 25-55 years old and had a minimum of three years teaching experience. Of the 122 mentor principals identified by the participants in this sample, $38 \%$ were female and $62 \%$ were male.

Within the resulting 128 mentoring ties, all four possible gender combinations were represented. Thirty-eight percent of the prospective education leaders were paired with a female principal mentor compared with $62 \%$ paired with a male mentor. The resulting 128 mentoring ties became the focus for this research. 


\subsection{Data Collection}

Prospective education leaders as the participants completed an online Qualtrics survey designed to address research questions. The survey items (except the demographics) allowed participants to indicate the extent to which survey statements described their mentoring experiences witha 4-point Likert scale with options as follows:(a) not descriptive,(b) somewhat descriptive,(c) moderately descriptive, and (d) very descriptive.

To address the first research question, the survey included 16 items from the Typology of Relational Embeddedness Network Data Survey (TRENDS) instrument (Hite et. al 2011). These survey items were analyzed to determine the degree and type of relational embeddedness in the mentoring relationship from the of the point of view of the prospective education leaders (see Appendix A). Survey items also addressed the second research question regarding internal factors of the partners in the mentoring relationship. The demographic of participant gender was used as an internal factor for both prospective education leaders and mentor principals. Internal behavior factors for mentees included the following: takes responsibility, contributes resources and asks for help). Eight behaviors were used to measure internal factors for mentor principals (i.e., listens, makes time, follows through, offers honest feedback, offers timely feedback, helps identify goals, helps achieve goals, assigns meaningful tasks, and provides support). All of these internal factors were cited in the literature as characteristics related to high-quality mentoring outcomes (Clutter buck 2005; 2012; Fletcher \& Ragins, 2007). The third research question examined two external factors within the environment in which the mentoring relationship was embedded (i.e., internship structure, and relationship history). The last section of the survey contained items regarding potential outcomes of mentoring relationships (i.e., amount learned and whether or not the prospective leader gained confidence).

\subsection{Data Analysis}

Once the Qualtrics surveys were submitted the names of the prospective education leaders and their mentor principals were removed to protect their confidentiality and each was assigned an identifying number. Data were then transferred to Excel to generate descriptive statistics (means and standard deviations) and to determine resulting values for each of the three social components. A dyadic tie was deemed to have a high level of a social component if its value was greater than one standard deviation above the average value among the respondents.

To statistically analyze the relational embeddedness in these mentoring ties, internal and external factors with low data counts of not descriptive and somewhat descriptive were re-coded into a single category. The categories of moderately descriptive and very descriptive were left intact. Thus, a classification of low, medium and high characterized participants' responses to survey items.

Data analysis utilized the internal and external factors as the independent variables, while the three social components identified in Hite's (2003) typology, as well as relational embeddedness degrees and types, were the dependent variables. Given that all of the variables were nominal/categorical, the Chi-Square Test for Independence was used to test for statistical associations. The standard for statistical significance was $\mathrm{p}$-value $\leq .05$.

\section{FINDINGS}

The findings of this study address the nature of relational embeddedness within the mentoring ties in this sample between prospective educational leaders and their mentor principals in an educational leadership preparation program. Findings also indicate a possible association between internal and external factors and relational embeddedness social components degrees and types.

\subsection{The Nature of Relational Embeddedness in Mentoring Ties}

The nature of the relational embeddedness and the resulting identification of degree and type are grounded in high extents of the three social components. Of the 128 mentoring ties in this sample, 40 (30\%) were relationally embedded consistent with other validated research conducted with the TRENDS survey instrument. Given the strategy of determining the threshold using the cutoff as equal to or less than one standard deviation, $70 \%$ of the mentoring ties were not relationally embedded (see Table 2). 
Relational Embeddedness in Mentoring Relationships between Prospective K-12 Education Leaders and Their Mentor Principals

Table2. Distribution of Mentoring Relationship Ties by Relational Embeddedness Degree, Type and Social Components ( $n=128$ ties)

\begin{tabular}{|c|c|c|c|c|}
\hline $\begin{array}{l}\text { Non-Relationally } \text { Embedded } \\
\text { Ties }\end{array}$ & $88(70 \%)$ & & & \\
\hline Relationally Embedded Ties & $40(30 \%)$ & & & \\
\hline $\begin{array}{l}\text { Degree of } \\
\text { Relational Embeddedness }\end{array}$ & $\begin{array}{l}\text { Distribution } \\
\text { of Degree }\end{array}$ & Type & $\begin{array}{l}\text { Distribution } \\
\text { of Type }\end{array}$ & $\begin{array}{l}\text { Social } \\
\text { Components }\end{array}$ \\
\hline \multirow[t]{3}{*}{ Uni-Dimensional } & $17(13 \%)$ & Personal & $5(4 \%)$ & Personal Relationship \\
\hline & & Competency & $5(4 \%)$ & Dyadic Interaction \\
\hline & & Hollow & $7(5 \%)$ & Social Capital \\
\hline \multirow[t]{3}{*}{ Bi-Dimensional } & $15(11 \%)$ & Isolated & $7(5 \%)$ & $\begin{array}{l}\text { Personal Relationship } \\
\text { Dyadic Interaction }\end{array}$ \\
\hline & & Functional & $4(3 \%)$ & $\begin{array}{l}\text { Dyadic Interaction } \\
\text { Social Capital }\end{array}$ \\
\hline & & Latent & $4(3 \%)$ & $\begin{array}{l}\text { Personal Relationship } \\
\text { Social Capital }\end{array}$ \\
\hline Full-Dimensional & $8(6 \%)$ & Full & $8(6 \%)$ & $\begin{array}{l}\text { Personal Relationship } \\
\text { Dyadic Interaction } \\
\text { Social Capital }\end{array}$ \\
\hline Totals & $128(100 \%)$ & & $128(100 \%)$ & \\
\hline
\end{tabular}

Table 2 shows the distributions of the three social components and supports the multi-dimensional nature of relational embeddedness degree and type within mentoring ties. Clearly, Hite's typology display a wider range of variation in relational embeddedness in this sample than would have been accounted for based exclusively on the dichotomy of strong or weak ties originally proposed by Granovetter (1973).

\subsection{Internal Factors of Mentoring Ties and the Nature of Relational Embeddedness}

The nature of the relational embeddedness in this sample showed patterns across all three social components as well as degrees and types. The gender of prospective education leaders, for example, was associated with the social component of personal relationship, with females demonstrating more relationally embedded ties. Female prospective education leaders also had more relationally embedded mentoring ties at each degree and type-with the exception of ties in the functional type with male prospective education leaders $(75 \%)$ and female $(25 \%)$.

Mentor principal gender was not significantly associated with relational embeddedness social components, degree or type. This finding indicates that prospective educational leaders were just as likely to be in relationally embedded mentoring ties with mentor principals of either sex. Findings did suggest, however, trend associations with the distribution of relational embeddedness type, given that more female mentor principals $(63 \%)$ had relationally embedded ties with full relational embeddedness. Male mentor principals, on the other hand, were in more relationally embedded ties with hollow embeddedness with its high extent of social capital, (i.e., obligations, resource acquisition and networking).

Many of the internal factors associated with relational embeddedness in the literature are consistent in this particular sample. For example, internal factors as follows: contributes resources, takes responsibility and asks for help were associated with the relational embeddedness of prospective education leaders. Internal factors listens, makes time, offers timely feedback and provides support for mentor principals were also associated with relational embeddedness.

\subsection{External Factors of Mentoring Ties and the Nature of Relational Embeddedness}

The design of the internship structure, an external factor, was not significantly associated with any social component, degree or type of relational embeddedness. However, findings do indicate a trend association between the full-time internship structure and the social component of social capital. This finding suggests that full-time internships may offer more opportunities to develop obligations, resource exchange and networking/brokering opportunities than part-time internships structures. The external factor of previous relationship history was significantly related to high extents of each of the three social components of relational embeddedness. 


\subsection{Summary of the Nature of Relational Embeddedness in Mentoring Ties}

Relational embeddedness in the mentoring ties between this sample of prospective education leaders and their mentor principals indicated clear variation in the nature of their ties. These ties demonstrate associations between internal and external factors and relational embeddedness social components, degrees and types. While outcomes of relational embeddedness were not specifically addressed in this study, the data supported a significant association between two beneficial mentoring outcomes cited in the literature-learned tricks of the trade and gained confidence as an effective school leader.

\section{DISCUSSION}

The section provides both theoretical and practical implications regarding the nature of relational embeddedness and mentoring ties for administrators of educational leadership preparation programs. When program internships are designed to include the possibility of enhancing variation within mentoring ties while promoting the potential impact of internal and external factors they may increase outcomes related to relational embeddedness and effective educational leadership preparation.

\subsection{Theoretical Implications}

The main theoretical implication of this research is that relational embeddedness is a multidimensional construct. Mentoring ties vary in the extent of relational embeddedness social components, degrees and types which support the argument of greater diversity among mentoring ties than indicated by the traditional strong and weak tie dichotomy. These findings lay theoretical groundwork for understanding potential advantages of relational embeddedness and mentoring tie evolution toward full relational embeddedness. Findings also indicate a wider range of potential resources which may lead to high-quality mentoring outcomes.

The variation and multidimensional nature of relational embeddedness is related to a variety of internal and external factors. The findings suggest the gender components of dyadic ties may be related to the development of relational embeddedness. For example, female prospective education leaders had higher extents of the social component personal relationship, as would be expected from the literature (see Noe, 1988).

Male prospective education leaders, on the other hand, had more relationally embedded mentoring ties related to the functional type. Furthermore, $75 \%$ of the mentoring ties in the functional type had male mentors as did $100 \%$ of the ties in the uni-dimensional type of hollow. These findings support Turban and Lee's (2007) claim that male mentors paired with either a male or female mentee offered organizational exposure and improved career benefits. Future research is needed to clarify the role of sex homophily and heterophily in mentoring ties and how it may affect relational embeddedness social components, types and degrees.

The findings of this study further indicate a consistent association between internal factors and the relational embeddedness in the mentoring ties. For example, mentoring ties in which prospective education leaders contributed resources and asked for help to a high degree were associated with all of the social components of relational embeddedness. This finding supports the literature which claims mentees who contributed resources such as ideas and interpersonal skills improved the quality of the relationship (Allen et al., 2006; Fletcher \& Ragins, 2007; Orland-Barak and Hasin, 2010; Turban \& Lee, 2007; Wanberg, Kammeyer-Mueller \& Marchese, 2006).

Internal factors of mentor principals also affected types and degrees of relational embeddedness. For example, mentor principals who listen and provide support promote the development of the social component personal relationship. Similarly, mentor principals that make time, follow through with commitments and offer honest and timely feedback may affect the development of the social component dyadic interaction. Lastly, when mentor principals identify and achieve goals, and assign meaningful tasks they may boost the development of the social capital component.

These findings suggest that internal factors of both mentors and mentees influence the development of relational embeddedness which may increase potential advantages and resource acquisition within their mentoring ties. External factors were also related to the development of relational embeddedness. Of the two external factors examined a previous relationship history was associated with degree of all three social components. 


\subsection{Practical Implications}

The variations found among the mentoring ties in this sample suggest practical implications for administrators of educational leadership preparation programs. As administrators recognize the potential for variation in relational embeddedness and the internal and external factors associated with its development they may design internship experiences that promote high-quality. The following section offers practical implications for administrators.

Given that participant gender was associated with relational embeddedness development, program administrators may intentionally match diverse gender compositions to increase potential advantages. For example, mentoring ties with two female partners had higher extents of personal relationship. Ties with two male partners had higher extents of dyadic interaction and social capital. When administrators match a diversity of partners potential advantages consisting of a broader range of social components may become available. Mentoring partnerships may also be matched according to personality or specialty areas. Future research is needed to clarify the role of homophily or heterophily in mentoring relationships as well as the potential benefits (outcomes) that may be associated with diverse mentoring compositions.

Internal factors associated with relational embeddedness may be enhanced through awareness and training. For example, specific training of characteristics such as taking responsibility for their own learning, contributing resources and asking for help may enable prospective education leaders to increase relational embeddedness development in their mentoring ties. Similarly, mentor principals trained and rewarded to offer timely feedback and assign meaningful tasks may increase the component of personal relationship. Increasing the effort needed for dyadic interaction processes and promoting the obligations and norms of social capital may also improve the possibility of acquiring critical resources needed by effective school leaders.

\section{CONClusion}

The work of effective school leadership is challenging. Mentoring relationships during internships appear to be a key social structure through which there sources of knowledge and skills may flow. However, while internships are among the most highly-valued experiences in education leadership preparation programs, they are still one of the most challenging features to measure effectively. Administrators must take the lead to prepare prospective education leaders by encouraging the development of relational embeddedness. Awareness and the development of relational embeddedness in dyadic mentoring ties may be one way to provide a bridge or conduit through which the critical resources necessary for effective school leadership may be acquired, exchanged and refined.

\section{REFERENCES}

[1] Allen, T. D., Lentz, E., \& Eby, L. T. (2006). Mentorship behaviors and mentorship quality associated with formal mentoring programs: Closing the gap between research and practice. Journal of Applied Psychology, 91(3), 567-578.

[2] Browne-Ferrigno, T. \& Muth, R. (2004). Leadership mentoring in clinical practice: Role socialization, professional development, and capacity building. Educational Administration Quarterly, 40(46), 8-494.

[3] Clutterbuck, D. (2005). Establishing and maintaining mentoring relationships: An overview of mentor and mentee competencies. Journal of Human Resource Management, 3(3), 2-9.

[4] Crow, G. M. (2012). School leader preparation: A short review of the knowledge base. Retrieved 7.13.2013. DOI: http://dera.ioe.ac.uk/id/eprint/5127

[5] Daresh, J. C. (2004). Mentoring school leaders: Professional promise or predictable problems. Educational Administration Quarterly, 40(4), 495-517.

[6] Davis, S., Darling-Hammond, L. LaPoint \& Meyerson, D. (2005). School leadership study: Developing successful principals.The Wallace Foundation. Stanford Educational Leadership Institute. DOI: https://edpolicy.stanford.edu/publications/products/949

[7] DiPaola, M., \& Tschannen-Moran, M. (2003). The principalship at a crossroads: A study of the conditions and concerns of principals. National Association of Secondary School Principals. NASSP Bulletin, 87(634), 43-65.

[8] Ehrich, L. C., Hansford, B., \& Tennent, L. (2004). Formal mentoring programs in education and other professions: A review of the literature. Educational Administration Quarterly, 40(4), 518-540. 
Relational Embeddedness in Mentoring Relationships between Prospective K-12 Education Leaders and Their Mentor Principals

[9] Elmore, R. F. (2008). School reform from the inside out: Policy, practice, and performance (Fifth Printing ed.). Cambridge, MA: Harvard Education Press.

[10] Fletcher, J. K., \& Ragins, B. R. (2007). Stone center relational cultural theory: A window on relational mentoring. In B. R. Ragins, \& K. E. Kram (Eds.), The handbook of mentoring at work: Theory, research, and practice (pp. 323-344). Thousand Oaks, CA: Sage Publications, Inc.

[11] Fullan, M. (2009). The principal and change. In M. Fullan (Ed.), The challenge of change: Start school improvement now! 2nd ed. (pp. 55-70). Thousand Oaks, CA: Corwin.

[12] Granovetter, M. S. (1973). The strength of weak ties. Journal of Sociology, 78(6), 1360-1380.

[13] Hite, J. M.(2003).Patterns of multi-dimensionality among embedded network ties:A typology of relational embeddedness in emerging entrepreneurial firms.Strategic Organization, 1(1), 9-49.

[14] Hite, J. M., \& Matthews, L. J. (2005). Assessing impact of leadership preparation programs: An analysis of the effect of student cohorts and administrative internships on the development of candidates' administrative networks. NCPEA Education Leadership Review, 6(1), 15-26.

[15] Hite, J. M. (2008). The role of dyadic multi-dimensionality in the evolution of strategic network ties. In J. A. C. Baum, \& T. J. Rowley (eds.), Network strategy: Advances in strategic management, (25), (pp. 133170).Emerald Group Publishing Limited.

[16] Hite, J. M., Wakkee, I., Hite, S. J., Sudweeks, R., \& Walker, T. D. (2011). Validating TRENDS - the typology of relational embeddedness network data survey. Presentation 31st Sunbelt International Social Network Conference. St. Petersburg, FL.

[17] Hite, J. M., Williams, E. J., \& Baugh, S. B. (2005). Multiple networks of public school administrators: An analysis of network content and structure. International Journal of Leadership in Education: Theory and Practice, 8(2), 91-122.

[18] Kram, K. E. (1983). Phases of the mentor relationship. Academy of Management Journal, 26(4), 608-625. DOI: $10.2307 / 255910$.

[19] Leithwood, K., Louis, K.S. Anderson, S. \& Wahlstrom, K. (2004). Learning from leadership project, The Wallace Foundation, The University of Minnesota; The University of Toronto. DOI: http://www.wallacefoundation.org/knowledge-center/school-leadership/key-research/documents/howleadership-influences-student-learning.pdf

[20] Levine, A. (2006). Educating school leaders. The education schools project. Retrieved February 21, 2012, DOI: http://www.edschools.org/pdf/Embargoed_Report_050315.pdf

[21] Merriam, S. (1983). Mentors and protégés: A critical review of the literature. Adult Education Quarterly, 33(3), 161-173.

[22] Noe, R. A. (1988). An investigation of the determinants of successful assigned mentoring relationships. Personnel Psychology, 41(3), 457-479.

[23] Orland-Barak, L., \& Hasin, R. (2010). Exemplary mentors' perspectives towards mentoring across mentoring contexts: Lessons from collective case studies. Teaching and Teacher Education, 26, 427-437.

[24] Turban, D. B., \& Lee, F. K. (2007). The role of personality in mentoring relationships. In B. R. Ragins, \& K. E. Kram (Eds.), The handbook of mentoring at work: Theory, research, and practice (pp. 323-344). Thousand Oaks, CA: Sage Publications, Inc.

[25] Wanberg, C. R., Kammeyer-Mueller, J., \& Marchese, M. (2006). Mentor and protégé predictors and outcomes of mentoring in a formal mentoring program. Journal of Vocational Behavior, 69(3), 410-423.

Citation: Maridee Beeston Ph.D. "Relational Embeddedness in Mentoring Relationships between Prospective K-12 Education Leaders and Their Mentor Principals" International Journal of Humanities Social Sciences and Education (IJHSSE), vol 7, no. 9, 2020, pp. 75-84. doi: https://doi.org/10.20431/2349-0381.0708007.

Copyright: (C) 2020 Authors. This is an open-access article distributed under the terms of the Creative Commons Attribution License, which permits unrestricted use, distribution, and reproduction in any medium, provided the original author and source are credited. 